\title{
PENGARUH METODE PREPARASI BROTH DAN JENIS PREKURSOR ZIRKONIUM PADA KARAKTERISTIK KERNEL YTTRIA-STABILIZED ZIRCONIA (YSZ)
}

\author{
Sarjono, Etty Mutiara, Erilia Yusnitha, Winter Dewayatna \\ Pusat Teknologi Bahan Bakar Nuklir - BATAN \\ Kawasan PUSPIPTEK Serpong Gd.20 Tangerang Selatan, Banten 15314 \\ e-mail: emutiara@batan.go.id
}

(Naskah diterima: 13-01-2020, Naskah direvisi: 29-01-2020, Naskah disetujui: 25-02-2020)

\begin{abstract}
ABSTRAK
PENGARUH METODE PREPARASI BROTH DAN JENIS PREKURSOR ZIRKONIUM PADA KARAKTERISTIK KERNEL YTTRIA-STABILIZED ZIRCONIA (YSZ). Telah dilakukan fabrikasi kernel yttria-stabilized zirconia (YSZ) secara gelasi eksternal dengan memvariasikan metode preparasi broth dan menggunakan dua jenis prekursor zirkonium. Pada preparasi larutan broth, dilakukan penambahan urea yang berfungsi sebagai agen presipitasi homogen untuk menghasilkan larutan sol dan sebagai agen penyedia porositas. Urea berfungsi sebagai agen presipitasi homogen jika ditambahkan pada suhu dekomposisi urea dan berfungsi sebagai agen penyedia porositas jika ditambahkan di bawah suhu dekomposisi. Jumlah urea yang ditambahkan divariasikan untuk mendapatkan nilai rasio mol urea/metal optimum yang ditentukan berdasarkan morfologi kernel tersinter. Prekursor zirkonium yang digunaan adalah zirkonium nitrat pentahidrat dan zirkonium oksinitrat hidrat. Pada penelitian ini, parameter proses pembentukan gel dari broth yang telah disiapkan, aging-washing-drying gel, kalsinasi dan penyinteran tidak divariasi. Karakterisasi produk meliputi pemeriksaan SEM kernel kering dan kernel tersinter untuk memperoleh data morfologi permukaan, pengukuran diameter dan densitas kernel tersinter, dan pemeriksaan XRD untuk penentuan fasa oksida zirkonium-yttrium yang dihasilkan. Berdasarkan pemeriksaan morfologi permukaan kernel tersinter yang dihasilkan, rasio mol urea/metal optimum untuk fungsinya sebagai agen presipitasi pada pereparasi sol adalah 1,0 dengan dekomposisi $80^{\circ} \mathrm{C}$ sementara rasio mol urea/metal optimum untuk fungsinya sebagai agen penyedia porositas gel adalah 1,5 pada suhu $50^{\circ} \mathrm{C}$. Kernel larutan padat $\mathrm{Y}_{0,15} \mathrm{Zr}_{0,85} \mathrm{O}_{1,93}$ atau $92 \mathrm{ZrO}_{2} .8 \mathrm{Y}_{2} \mathrm{O}_{3}$ diperoleh dari prekursor $16 \%$ mol yttrium nitrat dan $84 \%$ mol zirkonium nitrat dengan fasa cubic dan densitas $5,5636 \mathrm{gram} / \mathrm{cc}$ atau $93,34 \%$ densitas teoritis. Kenaikan konsentrasi prekursor menghasilkan kernel dengan diameter lebih besar. Diameter kernel yang mendekati 0,5 mm diperoleh dari broth dengan konsentrasi prekursor $0,855 \mathrm{~mol} / \mathrm{L}$ yaitu $0,510 \mathrm{~mm}$. Untuk mendapatkan kernel dengan diameter sesuai spesifikasi desain bahan bakar TRISO dapat dilakukan dengan penyesuaian jumlah prekursor dalam umpan atau broth.
\end{abstract}

Kata kunci: kernel YSZ, sol-gel, dekomposisi urea, gelasi eksternal, TRISO, morfologi. 


\begin{abstract}
THE INFLUENCE OF SOL PREPARATION METHOD AND TYPE OF ZIRCONIUM PRECURSOR ON THE CHARACTERISTIC OF YTTRIA-STABILIZED ZIRCONIA (YSZ) KERNEL. Fabrication of yttria-stabilized zirconia (YSZ) kernel by external gelation method has been done. Urea was used in the broth preparation to serve as: 1) as homogenous precipitation agent to produce sol when added at decomposing temperature of urea and 2) as pore promoter when added at below decomposing temperatures of urea. The research used urea in varied mol urea/metal ratio to obtain an the optimum value based on the resulted morphological properties of the sintered kernel. The zirconium precursor used was zirconium oxynitrate hydrate. Characterization of the kernel products include examination with SEM to study the morphological properties of the dried and sintered kernels, measurement of diameter and density of the sintered kernel, and XRD examination to determine the phase of the resulted solid solution of zirconium-yttrium oxide. Based on the morphological examination, the optimized addition of urea according to its function: 1) as precipitation agent in the sol preparation, mol urea/metal ratio of 1.0 at decomposing temperature of $80^{\circ} \mathrm{C}$ and 2) as porosity generation in the gel microsphere, mol urea/metal ratio of 1.5 at addition temperature of $50^{\circ} \mathrm{C}$. The $X R D$ examination shows that a mixture of $16 \% \mathrm{~mol}$ yttrium nitrate dan $84 \%$ mol zirkonium nitrate has resulted in solid solution of $\mathrm{Y}_{0,15} \mathrm{Zr}^{0,85} \mathrm{O}_{1,93}$ atau $92 \mathrm{ZrO}_{2} .8 \mathrm{Y}_{2} \mathrm{O}_{3}$ kernels with cubic phase. Increase in precursors concentration in broth has resulted in increase in the diameter of the sintered YSZ kernel, where kernels with average diameter of 0,510 $\mathrm{mm}$ was obtained from 0,855 mol/L precursors in broth. Kernels with desired diameter can be prepared by tuning of precursors concentration in broth.
\end{abstract}

Keywords: YSZ kernel, sol-gel, preneutralization, urea decomposition, external gelation, TRISO 


\section{PENDAHULUAN}

Reaktor daya temperatur tinggi (High Temperatur Gas-cooled Reactor, HTGR) merupakan reaktor pembangkit listrik tenaga nuklir generasi IV. Reaktor ini mempunyai keunggulan pada tingkat keselamatan operasi yang tinggi dan sistem kogenerasi, yaitu pemanfaatan panas untuk proses industri di samping untuk menghasilkan listrik. Reaktor HTGR dengan bahan bakar kernel $\mathrm{UO}_{2}$ terlapis TRISO (TRistructuralISOtropic) memiliki sistem keselamatan pasif yang menjamin lepasan radiasi dan hasil fisi sangat minimum ke lingkungan dalam kondisi apapun termasuk kondisi kecelakaan parah[1]. Lapisan TRISO akan bertindak sebagai pengungkung hasil fisi baik pada operasi normal, kondisi kecelakaan maupun pada saat dilimbahkan. Disamping itu, gas helium sebagai pendingin bahan bakar HTGR merupakan gas inert yang tidak akan bereaksi dengan material reaktor dan tidak menjadi radioaktif walaupun terekspos radiasi neutron[2].

Kernel $\mathrm{UO}_{2}$ bahan bakar untuk HTGR yang belum dilapis TRISO disyaratkan memiliki diameter $500 \pm 20 \mu \mathrm{m}$, densitas yang mendekati densitas teoritis, sferisitas tinggi, kekasaran permukaan minimal dan bebas retak. Persyaratan ini bertujuan untuk menjamin keseragaman temperatur disetiap partikel pada bahan bakar HTGR untuk tranfer panas yang efektif dan dan menghindari terjadinya swelling dengan cara mengakomodasi dan pengungkungan hasil fisi[3,4]. Diameter dan densitas kernel menentukan jumlah kandungan bahan fisil yang terbentuk dalam kernel, sementara deviasi pada sferisitas berkontribusi pada keberadaan stress lokal pada lapisan TRISO yang merupakan titik lemah kernel terlapis[5].

Pusat Teknologi Bahan Bakar Nuklir (PTBBN) memiliki peralatan sol-gel yang merupakan sarana untuk melakukan pengembangan teknologi fabrikasi bahan bakar bentuk kernel/mikrosfir skala laboratorium dengan proses gelasi eksternal. Penelitian fabrikasi bahan bakar kernel HTGR di PTBBN dilakukan menggunakan bahan analog $\mathrm{UO}_{2}$ yaitu yttria-stabilized zirconia. Hingga saat ini, proses fabrikasi bahan bakar bentuk kernel masih mempunyai masalah untuk memperoleh kernel yang sferis dengan diameter yang memenuhi syarat sebagai umpan proses pelapisan TRISO. Permasalahan di atas akan terjawab bila diketahui faktor-faktor yang mempengaruhi sferisitas kernel dan pencapaian diameter kernel yang diinginkan melalui pelaksanaan penelitian di laboratorium. Beberapa referensi menyatakan bahwa perlu dilakukan pengkondisian sol umpan (broth) untuk mendapatkan kernel yang sferis dan peningkatan konsentrasi $\mathrm{Y}-\mathrm{Z}$ dalam sol umpan untuk peningkatan diameter kernel[6-9]. Bahan yang dapat digunakan sebagai pengkondisi umpan antara lain larutan $\mathrm{NH}_{4} \mathrm{OH}$, urea, PVA (polyvinyl alcohol) dan THFA (tetrahydrofurfuryl alcohol). Selain sebagai pengkondisi sol umpan, urea juga dapat berperan sebagai pore promoter untuk mengurangi kemungkinan terjadinya retak pada kernel yang dikalsinasi. Untuk itu perlu dilakukan eksperimen fabrikasi kernel 8YSZ guna mempelajari peran urea sebagai pengkondisi (prenetralisasi) larutan umpan sol zirkonium dan yttrium nitrat dibandingkan dengan larutan $\mathrm{NH}_{4} \mathrm{OH}$. Jumlah urea yang didekomposisi untuk proses prenetralisasi larutan umpan dan ditambahkan sebagai pore promoter akan divariasikan guna mengetahui pengaruhnya terhadap tingkat sferitas kernel. Jumlah urea yang optimal digunakan pada penyiapan larutan umpan dengan memvariasikan konsentrasi $\mathrm{Y}-\mathrm{Zr}$ dalam sol umpan untuk mendapatkan relasi konsentrasi dengan diameter kernel. Hasil analisis dan interpretasi dari data eksperimen akan dijadikan sebagai panduan dalam menyiapkan larutan umpan untuk memperoleh kernel 8YSZ sferisitas tinggi dengan diameter yang diinginkan. 


\section{Gelasi Eksternal}

Kernel $\mathrm{UO}_{2}$ HTGR dapat diproduksi melalui proses sol-gel dengan gelasi eksternal atau internal. Pada fabrikasi kernel dengan proses sol-gel, cara gelasi eksternal dipilih karena prosesnya sederhana dan dapat dilakukan pada temperatur kamar. Untuk mendapatkan kernel HTGR sesuai sfesifikasi, tahapan proses sol-gel yang harus dilakukan adalah penyiapan umpan sol, gelasi sol (gel casting), aging-washingdrying hasil gelasi dan proses perlakuan panas gel kering agar diperoleh kernel tersinter. Parameter-parameter pada proses sol-gel mempengaruhi karakteristik kernel yang dihasilkan, antara lain kondisi umpan sol seperti jenis prekursor, konsentrasi logam berat dalam umpan, viskositas, jumlah kandungan bahan aditif, parameter peralatan sol-gel (laju alir umpan, laju alir gas $\mathrm{NH}_{3}$, frekuensi vibrator nozzle) dan parameter proses perlakuan panas[10-13].

Pada proses gelasi eksternal, agar menghasilkan gel yang sferis maka sebelum dilewatkan pada nozzle peralatan gel casting, pada sol umpan perlu ditambahkan bahan pengkondisi agar terjadi proses gelling dan pengatur viskositas untuk pembentukan gel sferis. Bahan tersebut berupa polimer organik yang larut dalam air. Polimer yang umum digunakan adalah PVA dengan penambahan aditif THFA. THFA berfungsi untuk melindungi PVA dari serangan asam sol umpan. Tetesan sol yang keluar dari nozzle cenderung bulat karena tegangan muka dari tetesan dipengaruhi oleh viskositasnya. Viskositas larutan umpan menghasilkan tetesan yang sferis berkisar antara 40-60 cP[14].

\section{Sferisitas Kernel}

Sferisitas kernel $\mathrm{UO}_{2}$ yang disyaratkan sebesar $\leq 1,2$ [15]. Pada gelasi eksternal, kernel $\mathrm{UO}_{2}$ sferisitas tinggi dapat diperoleh dengan melakukan gelasi yang cepat terhadap larutan uranil nitrat yang tidak stoikiometris (larutan kekurangan asam) yang dikenal dengan larutan acid deficient uranyl nitrate (ADUN). Derajad kekurangan asam (acid deficiency) adalah rasio $\mathrm{NO}_{3}-\mathrm{U}$ yang lebih kecil dari 2 yang mengkondisikan larutan sol umpan secara termodinamik berada pada kondisi paling cepat untuk terjadi proses gelasi [16]. Gelasi cepat dilakukan dengan cara eksposur tetesan sol ADUN yang keluar dari nozzle ke media gas $\mathrm{NH}_{3}$ sehingga terjadi gelasi cepat di permukaan tetesan (pembentukan kulit) dalam waktu kurang dari 0,02 detik[17]. Dengan cara ini, sferisitas sol sejak keluar dari nozzle tetap dapat dipertahankan sampai proses gelasi berlangsung sempurna. Proses gelasi akan menghasilkan gel yang lebih baik apabila sebelum tereksposur di media gas $\mathrm{NH}_{3}$, tetesan sol ADUN yang keluar dari nozzle terlebih dahulu terekspos ke media udara. Di media udara, tetesan akan mendapat kesempatan untuk menjadi tetesan yang sferis dan mengalami penguatan permukaan sebelum proses gelasi dimulai sehingga kesferisannya tidak mudah terdeformasi di tahapan proses selanjutnya[18].

Larutan ADUN diperoleh dengan melakukan pre-netralisasi terhadap larutan umpan uranil nitrat yaitu dengan menambahkan larutan $\mathrm{NH}_{4} \mathrm{OH}$ dalam jumlah tertentu sehingga ion $\mathrm{NH}_{4}{ }^{+}$menetralkan sebagian ion $\mathrm{NO}_{3}{ }^{-}$dalam larutan umpan. Larutan $\mathrm{NH}_{4} \mathrm{OH}$ dimasukkan sedikit demi sedikit ke dalam larutan umpan yang dipanaskan pada temperatur berkisar $80-85^{\circ} \mathrm{C}$ sambil terus dilakukan pengadukan. Dengan demikian, pada proses ini diharapkan larutan $\mathrm{NH}_{4} \mathrm{OH}$ akan terdispersi merata dan proses prenetralisasi akan homogen di seluruh bagian larutan umpan. Berbeda dengan uranil nitrat yang menghasilkan kernel $\mathrm{UO}_{2}$ kristalin, bila umpan yang digunakan adalah $\mathrm{ZrO}\left(\mathrm{NO}_{3}\right)_{2} .2 \mathrm{H}_{2} \mathrm{O}$ sebagai bahan analog uranil nitrat maka gelasi cepat dari larutan umpan yang diprenetralisasi dengan $\mathrm{NH}_{4} \mathrm{OH}$ akan menghasilkan kernel yang amorf dengan potensi retak/pecah yang tinggi[19]. 
Hal ini disebabkan oleh sifat kimiawi zirkonium yang berbeda dengan uranium. Pre-netralisasi larutan umpan zirkonium nitrat dapat dilakukan dengan menggunakan urea sebagai pengganti larutan $\mathrm{NH}_{4} \mathrm{OH}$. Ion $\mathrm{NH}_{4}{ }^{+}$ untuk pre-netralisasi larutan umpan dihasilkan dari proses dekomposisi urea yang berlangsung efektif pada temperatur sekitar $85^{\circ} \mathrm{C}$ selama 60 menit dengan konsentrasi urea sebesar 6 kali mol heavy metal yang dilarutkan[20, 21].

\section{Diameter kernel}

Diameter kernel $\mathrm{UO}_{2}$ sinter HTGR yang dipersyaratkan sebesar $500 \mu \mathrm{m}[22,23]$. Diameter kernel sangat tergantung pada jumlah heavy metal dalam larutan umpan pada parameter peralatan sol-gel yang dijaga tetap (laju alir umpan, diameter nozzle, laju alir gas $\mathrm{NH}_{3}$ )[24].

\section{Zirkonia sebagai material analog}

Pada proses pelapisan TRISO (yaitu pelapisan buffer, inner PyC, SiC dan outer PyC), misalnya, akurasi dan uniformitas hasil pelapisan merupakan dua persyaratan yang krusial. Upaya untuk mempelajari pengaruh perbedaan parameter proses deposisi pada karakteristik hasil pelapisan biasanya digunakan bahan pengganti yang tidak radioaktif sebagai bahan kernel. Pada penggunaan zirkonium dioksida sebagai bahan analog $\mathrm{UO}_{2}$ perlu dilakukan penambahan bahan doping untuk menstabilkan fasa zirkonium dioksida pada suhu tinggi mengingat proses pelapisan TRISO berjalan pada rentang suhu $1250^{\circ} \mathrm{C}-1500^{\circ} \mathrm{C}[12]$. Penyetabilan zirkonium dioksida diperlukan mengingat ada 3 bentuk kristalin (fasa) zirkonium pada beberapa level suhu yaitu: kubik (c) (dari $2680^{\circ} \mathrm{C}$ sampai $2370^{\circ} \mathrm{C}$ ); tetragonal (t) (dari $2370^{\circ} \mathrm{C}$ sampai $1170^{\circ} \mathrm{C}$ ); monoklinik (m) (dari $1170^{\circ} \mathrm{C}$ sampai suhu kamar). Fasa monoklinik (m) merupakan fasa zirkonium yang lebih stabil. Pencampuran zirkonium dioksida dengan jenis oksida yang memiliki fasa kubik seperti $\mathrm{MgO}, \mathrm{CaO}, \mathrm{Y}_{2} \mathrm{O}_{3}$ dan $\mathrm{CeO}_{2}$ dapat menunda terjadinya fasa transformasi, misalnya dari monoklinik ke tetragonal, sehingga kristal zirkonia akan tetap berada pada fasa kubik atau tetragonal pada suhu kamar. Fasa kubik $\mathrm{ZrO}_{2}$ yang tetap stabil di suhu kamar biasanya disebut fully stabilized zirconia (FSZ), dan fasa ini dapat disintesis melalui doping 8\% Yttria $\left(\mathrm{Y}_{2} \mathrm{O}_{3}\right)[25]$. Komposisi stokiometri prekursor yttrium nitrat $16 \mathrm{~mol} \%$ yang ditambahkan pada larutan prekursor zirkonium nitrat akan menghasilkan $8 \mathrm{~mol} \%$ $\mathrm{Y}_{2} \mathrm{O}_{3}$ pada larutan padat $\mathrm{Y}_{2} \mathrm{O}_{3}-\mathrm{ZrO}_{2}$ atau disebut juga larutan padat 8YSZ setelah perlakuan panas kalsinasi[26].

\section{METODOLOGI}

Diagram alir eksperimen disajikan pada Gambar 1. Proses fabrikasi fabrikasi kernel YSZ mencakup empat proses utama yaitu 1) penyiapan larutan prekursor campuran $\mathrm{Zr}+\mathrm{Y}$ nitrat untuk berikutnya ditambahkan urea dan bahan aditif, 2) pembentukan droplet dengan kontrol parameter seperti laju alir umpan, frekuensi getaran nozzle, laju gas $\mathrm{NH} 3,3$ ) aging, washing, drying, dan 4) perlakuan seperti penguapan kandungan air, kalsinasi dan penyinteran.

\section{Penyiapan larutan umpan}

Sejumlah mol $\mathrm{ZrO}\left(\mathrm{NO}_{3}\right)_{2} .6 \mathrm{H}_{2} \mathrm{O}$ dan $\mathrm{Y}\left(\mathrm{NO}_{3}\right)_{3} .6 \mathrm{H}_{2} \mathrm{O}$ dengan kandungan yttrium nitrate $16 \%$ mol dilarutkan dalam $200 \mathrm{~mL}$ air demineral pada suhu $80^{\circ} \mathrm{C}$. Sejumlah urea dengan rasio $\mathrm{mol}$ urea/metal tertentu ditambahkan dengan tetap menjaga suhu $80^{\circ} \mathrm{C}$ selama waktu tertentu. Untuk mempelajari komposisi optimum urea yang perlu ditambahkan, dilakukan variasi jumlah penambahan urea dengan membagi porsi urea menjadi dua bagian. Bagian pertama, adalah jumlah urea dengan rasio mol urea/metal sama dengan 1, ditambahkan pada kondisi suhu campuran larutan metal nitrat pada $80^{\circ} \mathrm{C}$ untuk mendapatkan dekomposisi urea dan diperoleh larutan sol terprenetralisasi atau acid deficient, kemudian bagian kedua adalah variasi jumlah urea dengan rasio mol urea/metal 
1,0, 1,5, dan 2,0 ditambahkan pada kondisi sol dengan suhu $50^{\circ} \mathrm{C}$. Selanjutnya larutan didingankan sampai suhu $30-40^{\circ} \mathrm{C}$ dan ditambahkan larutan PVA $8 \%$ dan THFA untuk mengatur viskositas pada 45-60 mPa.s. Campuran larutan ini dinamakan broth dan diaduk selama minimal
4 jam untuk mendapatkan homogenitas, dan selanjutnya campuran ini dimasukkan ke bejana umpan peralatan sistim sol-gel dan dibiarkan selama semalam untuk menghilangkan gelembung dalam larutan umpan.

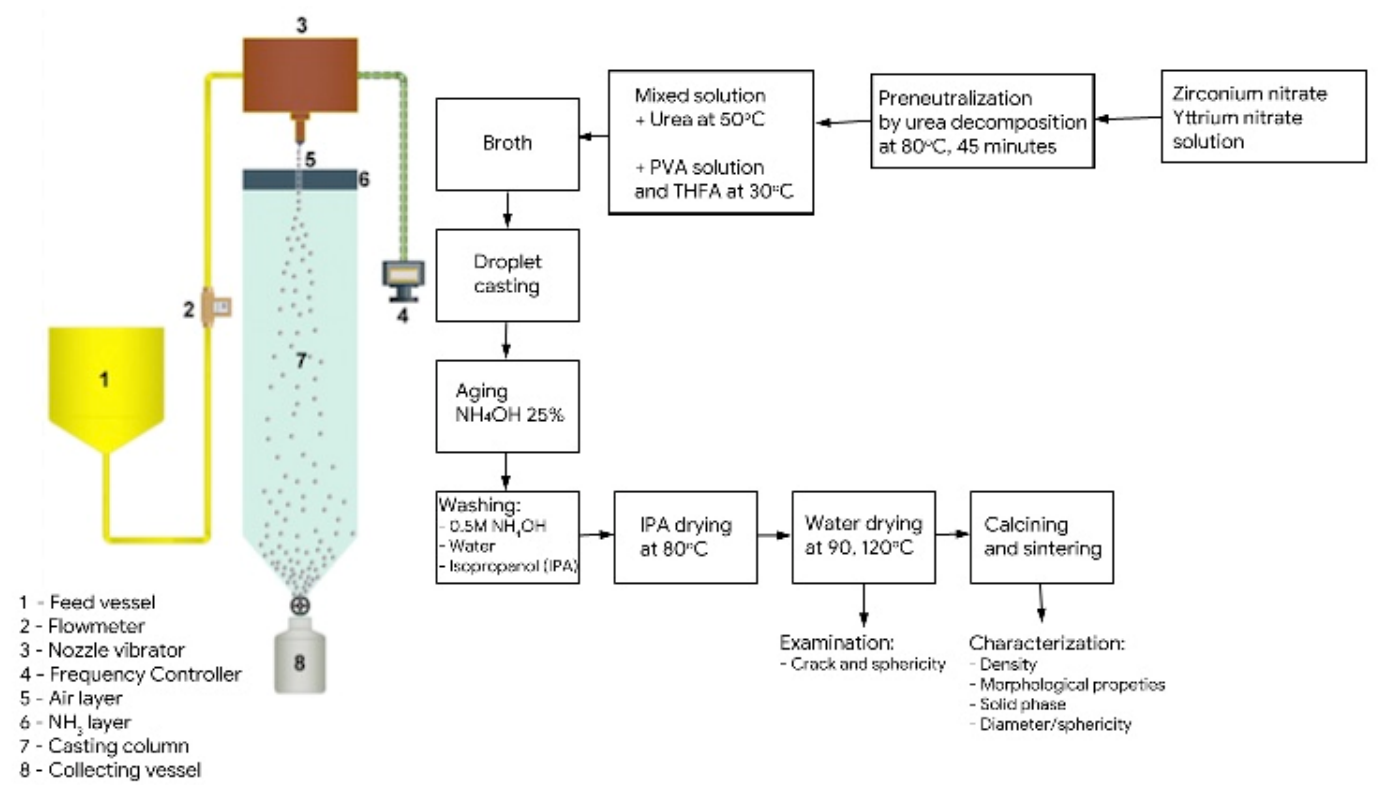

Gambar 1. Diagram alir eksperimen

Pada fabrikasi kernel 8YSZ, proses pre-netralisasi diperlukan untuk presolidifikasi permukaan yang cepat ketika droplet umpan melewati kolom gas amonia. Presolidifikasi bertujuan untuk mempertahankan bentuk sferis gel ketika jatuh ke dalam kolom $\mathrm{NH}_{4} \mathrm{OH}$ untuk penyempurnaan proses gelasi. Kondisi prenetralisasi atau acid deficient adalah kondisi keasaman larutan sedemikian sehingga kenaikan $\mathrm{pH}$ sedikit saja akan mampu dengan cepat mengkonversi larutan sol menjadi gel. Proses pre-netralisasi dapat dilakukan dengan teknik presipitasiredispersi, yaitu mereaksikan umpan campuran larutan zirkonium dan yttrium nitrat dengan $\mathrm{OH}^{-}$yang berasal dari peruraian tetesan $\mathrm{NH}_{4} \mathrm{OH}$ dan terbentuk presipitat zirkonium hidroksida $\left(\mathrm{ZrO}(\mathrm{OH})_{2}\right)$ dan $\mathrm{Y}(\mathrm{OH})_{3}$ yang kemudian terdispersi kembali melalui pengadukan. Cara lain untuk mendapatkan larutan yang acid deficient adalah pembentukan presipitat homogen melalui reaksi larutan metal nitrat dengan $\mathrm{OH}^{-}$yang berasal dari dekomposisi urea pada suhu 80 sampai $85^{\circ} \mathrm{C}$. Dekomposisi urea dalam air sangat lambat dan hasil presipitat yang bersifat nano tersebar ke seluruh volume larutan, sehingga pre-netralisasi cara ini cenderung memberikan tingkat acid deficient yang homogen, sedangkan kondisi acid deficient oleh proses presipitasi-redispersi lebih cenderung menyebabkan lokalisasi pembentukan presipitat.

Selama proses prenetralisasi dengan metode dekomposisi urea, species hasil hidrolisis zirkonium $\mathrm{ZrO}^{2+}$ dan hasil hidrolisis yttrium $\mathrm{Y}^{3+}$ bereaksi dengan $\mathrm{OH}^{-}$ dari hasil dekomposisi urea.

$$
\begin{aligned}
& \mathrm{CO}\left(\mathrm{NH}_{2}\right)_{2}+3 \mathrm{H}_{2} \mathrm{O} \rightarrow 2 \mathrm{NH}_{4}^{+}+2 \mathrm{OH}^{-}+\mathrm{CO}_{2}(1) \\
& \mathrm{ZrO}^{2+}+2 \mathrm{OH}^{-} \rightarrow \mathrm{ZrO}(\mathrm{OH})_{2} \\
& \mathrm{Y}^{3+}+3 \mathrm{OH}^{-} \rightarrow \mathrm{Y}(\mathrm{OH})_{3}
\end{aligned}
$$




\section{Pembentukan droplet dan gelasi}

Larutan umpan untuk proses pembentukan droplet diumpankan dari tangki umpan ke vibrating nozzle dengan udara tekan melalui pipa kecil. Aliran laminar yang dihasilkan dari vibrating nozzle akan menghasilkan droplet yang seragam. Tegangan permukaan akan menyebabkan droplet dengan bentuk bulat pada udara atmosfer sebelum masuk dalam atmosfer ammonia untuk proses pre-solidifikasi. Dari hasil pre-solidifikasi partikel-partikel sferis akan ditampung pada tabung yang berisi ammonium hidroksida.

\section{Aging, Washing, Drying}

Proses aging merupakan penyempurnaan reaksi konversi sol menjadi gel di seluruh bagian kernel. Mikrosfir gel yang diperoleh dikenakan proses aging (pematangan) dalam bejana berputar menggunakan larutan amonia $25 \%$ selama 2jam. Dalam proses ini, reaksi gelasi terus berlanjut sampai selesai ke pusat mikrosfer. Proses selanjutnya adalah mencuci dengan larutan amonia encer $0,5 \mathrm{M}$ untuk menghilangkan garam (amonium nitrat) dan pada saat yang sama untuk menghindari repeptisasi mikrosfer gel. Proses pencucian dilakukan dua kali menggunakan larutan amonia encer, masing-masing selama 15 menit. Sebagai produk samping terbentuk amonium nitrat yang tertinggal dalam cairan larutan amonia yang kemudian dihilangkan dengan pencucian menggunakan air demineral sebanyak delapan kali atau lebih pencucian. Konduktivitas listrik dari air limbah diukur. Pencucian dengan air dianggap cukup ketika angka di bawah $20 \mu \mathrm{S} / \mathrm{cm}$ terpenuhi. Mikrosfer yang telah dicuci dengan air kemudian dikenai 4 kali 30 menit pengeringan dewatering dengan isopropil alkohol (IPA). Pencucian isopropil alkohol dimaksudkan untuk menghilangkan air dan amonium nitrat yang tersisa dan aditif polimer lainnya pada permukaan mikrosfer. Pencucian dengan IPA bertujuan untuk menghilangkan kandungan air pada kernel. Proses pencucian ini melalui 2 tahap dengan recycled IPA (komposisi air 80 - $150 \mathrm{~g} / \mathrm{l}$ ) dan
2 tahap pencucian dengan IPA murni (komposisi air $\leq 1 \mathrm{~g} / \mathrm{l}$ ). Setiap tahap berlangsung selama 15 menit dalam keadaan temperatur ruangan dan waktu dripping 10 menit. Mikrosfer gel dikeringkan pada suhu $80^{\circ} \mathrm{C}$ selama 8 jam untuk memungkinkan sebagian besar IPA di permukaan dan bagian dalam kernel menguap perlahan. Selanjutnya, mikrosfer dipanaskan hingga 90 dan $120^{\circ} \mathrm{C}$ pada laju $0,5^{\circ} \mathrm{C} /$ menit selama 4 jam pada setiap suhu.

\section{Kalsinasi-Sintering}

Kalsinasi berjalan pada suhu 200 , 400 and $600^{\circ} \mathrm{C}$ dengan laju pemanasan $0,5^{\circ} \mathrm{C} /$ menit dan waktu tahan 4 jam di masing-masing temperatur dan didinginkan sampai suhu ruang. Sampel yang telah dikalsinasi dan didinginkan selanjutnya disinter dengan laju pemanasan $1^{\circ} \mathrm{C} /$ menit sampai suhu $1350^{\circ} \mathrm{C}$ dengan waktu tahan (soaking time) 4 jam.

Pemeriksaan visual menggunakan Scanning Electron Microscope (SEM) dilakukan pada kernel kering dan kernel tersinter untuk mempelajari morfologi permukaan dan selanjutnya pengukuran densitas dilakukan pada kernel tersinter untuk mempelajari keterkaitan morfologi dan densitas. Karakterisasi lain yang dilakukan adalah pengukuran diameter untuk mempelajari pengaruh konsentrasi metal pada diameter kernel dan pemeriksaan fasa dengan X-Ray Diffractometer (XRD) untuk menentukan fasa larutan padat zirkonia-yttria kernel tersinter.

\section{HASIL DAN PEMBAHASAN}

Gambar 2 menunjukkan visual SEM dari kernel YSZ dengan preparasi umpan tanpa penambahan urea. Gel kering hidroksida cenderung memiliki struktur yang amorf, dan struktur ini kurang memiliki porositas yang mencukupi sebagai jalur keluar gas-gas dekomposisi bahan aditif dan gas-gas produk kalsinasi yang pada akhirnya tekanan gas tersebut menyebabkan kernel menjadi retak atau pecah. Penambahan urea membantu pembentukan porositas sebelum terjadi dekomposisi bahan aditif dan proses 
kalsinasi. Pada proses penguapan air pada proses pengeringan masing-masing selama 4 jam pada suhu $90^{\circ} \mathrm{C}$ dan $120^{\circ} \mathrm{C}$, urea akan tetap tertinggal di dalam kernel dalam bentuk kristalin. Pada perlakuan panas kalsinasi dan penyinteran, urea mulai terdekomposisi secara lambat menjadi gas $\mathrm{NH}_{3}$ dan $\mathrm{CO}_{2}$ pada suhu $133^{\circ} \mathrm{C}$ dan termolisis urea menjadi lebih cepat pada suhu $150^{\circ} \mathrm{C}$ ke atas [27]. Pada suhu tersebut pelepasan produk dekomposisi urea keluar dari kernel yang berjalan secara lambat tidak menyebabkan terjadinya keretakan kernel sebagaimana ditampilakan pada Gambar 2b.

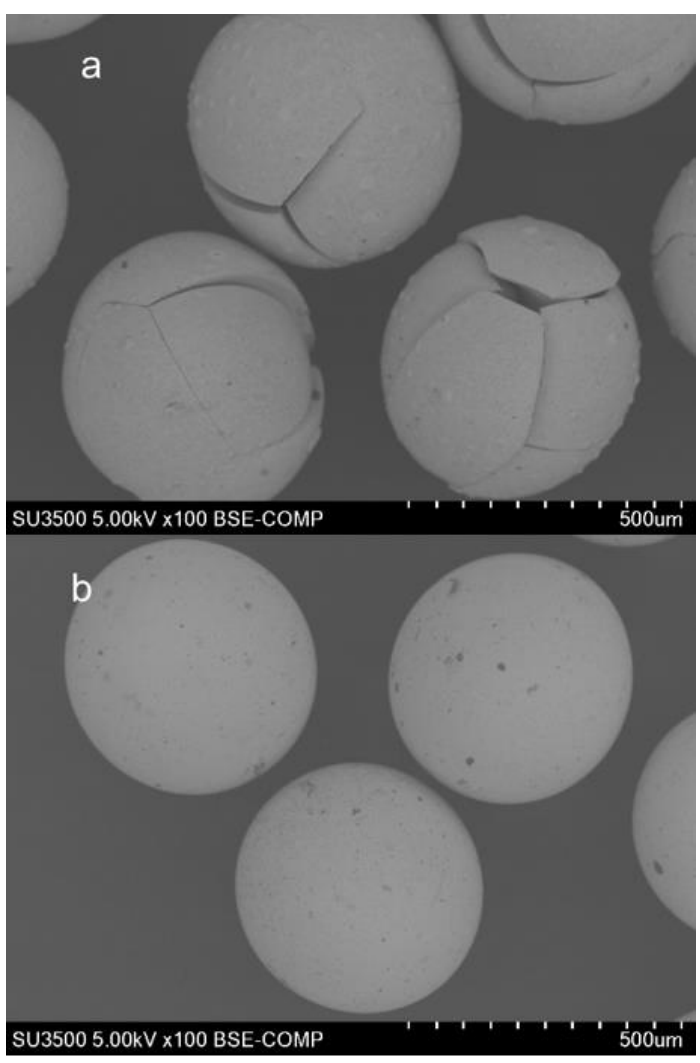

Gambar 2. Kernel sinter YSZ dengan preparasi

a) tanpa penambahan urea

b) dengan penambahan urea

Pada perlakuan panas pada suhu $200^{\circ} \mathrm{C}$ selama $4 \mathrm{jam}$, bahan polimer aditif (PVA dan THFA) dan $\mathrm{NH}_{4} \mathrm{NO}_{3}$ sebagai produk samping proses gelasi mulai terdekomposisi menjadi gas. Dengan adanya jalur porositas yang terbentuk selama dekomposisi urea, produk gas-gas dari bahan aditif dan amonium nitrat akan meninggalkan kernel tanpa menimbulkan tekanan yang besar dan mengakibatkan kernel retak atau pecah.

Proses pre-netralisasi pada penyiapan umpan menggunakan metode dekomposisi urea dalam air memiliki tantangan tersendiri. Pada percobaan awal jumlah urea sebanyak 2,5 kali mol metal nitrat dan dekomposisi pada suhu sekitar $80^{\circ} \mathrm{C}$ $85^{\circ} \mathrm{C}$ menyebabkan konversi larutan menjadi sol dalam waktu yang singkat (15 menit) sehingga kontrol menjadi sukar dilakukan mengingat pada saat pendinginan larutan urea akan tetap terdekomposisi sampai suhu $70^{\circ} \mathrm{C}$. Oleh karena itu pada penelitian ini dilakukan optimasi proses dekomposisi urea dalam air pada suhu $80^{\circ} \mathrm{C}$ selama 45 menit dengan rute 1) jumlah urea 0,5 kali mol prekursor didekomposisikan pada $80^{\circ} \mathrm{C}$ dan 1 kali mol prekursor ditambahkan pada suhu $\left.50^{\circ} \mathrm{C}, 2\right)$ jumlah urea 1,0 kali mol prekursor didekomposisikan pada $80^{\circ} \mathrm{C}$ dan $0,5 \mathrm{kali}$ mol prekursor ditambahkan pada suhu $50^{\circ} \mathrm{C}, 3$ ) jumlah urea 1,0 kali mol prekursor didekomposisikan pada $80^{\circ} \mathrm{C}$ dan $1,0 \mathrm{kali}$ mol prekursor ditambahkan pada suhu $50^{\circ} \mathrm{C}$, dan 4) jumlah urea 1,0 kali mol prekursor didekomposisikan pada $80^{\circ} \mathrm{C}$ dan $1,5 \mathrm{kali}$ mol prekursor ditambahkan pada suhu $50^{\circ} \mathrm{C}$ dengan kernel tersinter ditampilkan pada Gambar 3.

Gambar 3 memperlihatkan sferisitas kernel tersinter dan morfologi permukaannya untuk masing-masing rute penambahan urea. Pada dekomposisi selama 45 menit dengan jumlah urea 0,5 kali mol prekursor, kernel secara visual kurang sferis dan sferisitas makin membaik pada rute 4 yaitu penambahan jumlah urea 1,0 kali mol prekursor didekomposisikan pada $80^{\circ} \mathrm{C}$ dan 1,5 kali mol prekursor pada suhu $50^{\circ} \mathrm{C}$. Sementara itu, untuk masing-masing rute menghasilkan morfologi atau kehalusan permukaan yang mirip. Meskipun penambahan urea pada suhu di bawah suhu dekomposisi dimaksudkan untuk menekan fenomana retak selama proses perlakuan panas, Gambar 3-b1, 3-b2, 3-b3 juga menunjukkan bahwa jumlah urea yang lebih besar pada suhu di bawah suhu dekomposisi $\left(50^{\circ} \mathrm{C}\right)$ memberikan perbaikan pada sferisitas 
kernel tersinter. Ini dapat dipahami bahwa urea merupakan basa lemah sehingga jumlah urea yang lebih banyak memberikan kondisi sol yang lebih acid deficient dan menyebabkan proses presolidifikasi permukaan gel yang lebih cepat saat tetesan umpan melewati kolom gas $\mathrm{NH}_{3}$.

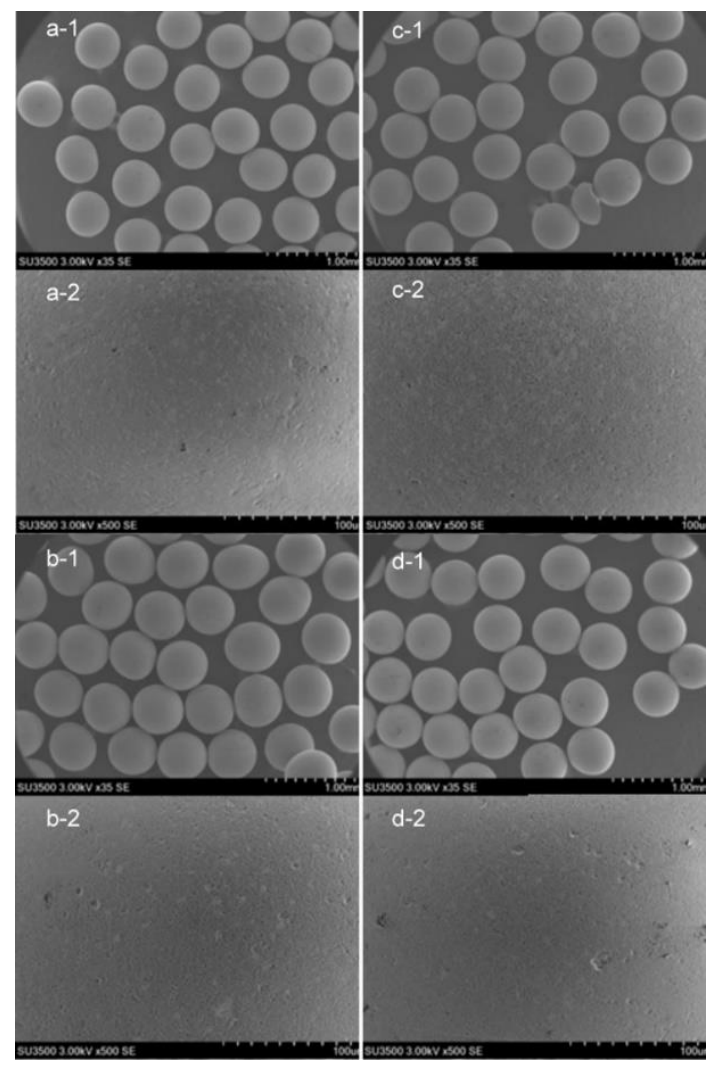

Gambar 3. Profil dan morfologi permukaan

a) a-1 sferisitas kernel YSZ tersinter dan a-2 morfologi permukaan dengan metode preparasi rute 1

b) b-1 sferisitas kernel YSZ tersinter dan b-2 morfologi permukaan dengan metode preparasi rute 2

c) c-1 sferisitas kernel YSZ tersinter dan c-2 morfologi permukaan dengan metode preparasi rute 3

d) d-1 sferisitas kernel YSZ tersinter dan d-2 morfologi permukaan dengan metode preparasi rute 4.

Dari hasil analisis di atas, dilakukan penelitian lebih lanjut untuk mempelajari pengaruh konsentrasi prekursor dalam broth pada diameter kernel tersinter penambahan urea mengikuti rute 4 , yaitu jumlah urea 1,0 kali mol prekursor didekomposisikan pada $80^{\circ} \mathrm{C}$ dan 1,5 kali mol prekursor ditambahkan pada suhu $50^{\circ} \mathrm{C}$.

Pengaruh konsentrasi prekursor pada diameter kernel tersinter disajikan pada Gambar 4, dimana kenaikan konsentrasi prekursor dalam umpan atau broth menghasilkan diameter kernel tersinter yang lebih besar, yaitu 0,570; 0,727; 0,812; dan $0,855 \mathrm{~mol} \mathrm{Y}-\mathrm{Zr}$ nitrat per mol broth memberikan rerata diameter kernel tersinter masing-masing 0,469; 0,477; 0,488; dan $0,510 \mathrm{~mm}$. Untuk mendapatkan diameter kernel tersinter yang diinginkan sesuai diameter kernel menurut disain reaktor dapat dilakukan penyesuaian konsentrasi prekursor dengan intrapolasi data di atas.

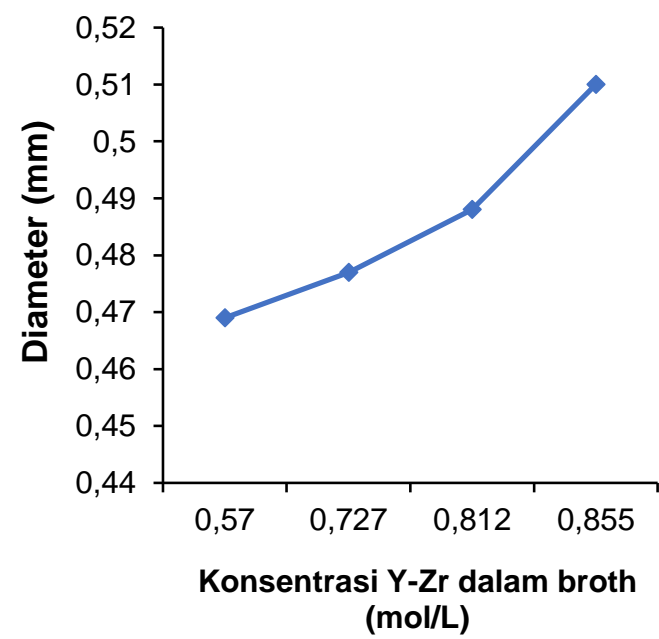

Gambar 4. Pengaruh konsentrasi Y-Zr dalam broth terhadap diameter kernel tersinter.

Gambar 5-a memperlihatkan distribusi homogenitas diameter kernel tersinter dan sferisitasnya, sementara Gambar 5-b merupakan visual kernel tersinter dari foto kamera, di mana optimasi metode prenetralisasi secara dekomposisi urea dengan rute 4 dengan konsentrasi 0,855 mol prekursor $\mathrm{Y}-\mathrm{Zr}$ nitrat memberikan homogenitas diameter dan sfesiritas yang secara visual cukup homogen. 


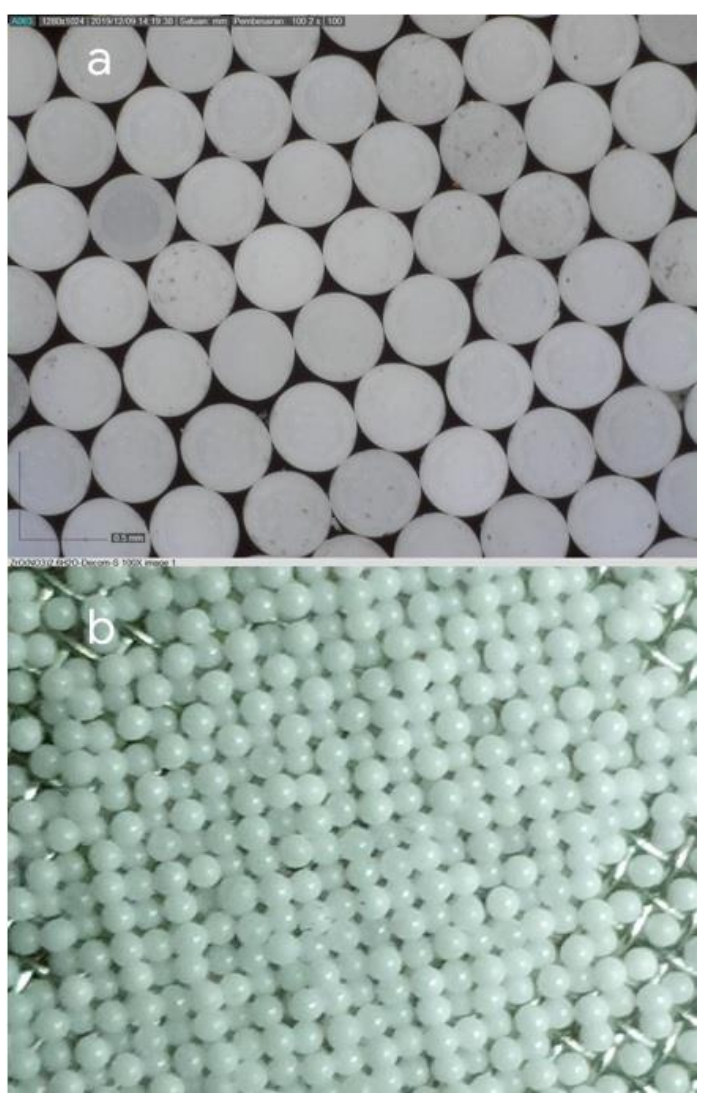

Gambar 5. Visual kernel 8YSZ tersinter

a) pembesaran 100 kali oleh mikroskop optik

b) foto kamera.

Hasil pemeriksaan fasa hasil sinter kernel dengan komposisi broth campuran $84 \%$ prekursor zirkonium nitrat dan $16 \%$ yttrium nitrat menghasilkan larutan padat dengan densitas 5,5636 gram/cc atau $93,34 \%$ densitas teoritis dengan fasa cubic yang bersesuaian dengan database ICDD no. 00-030-1468 dengan formulasi kimia $\mathrm{Y}_{0,15} \mathrm{Zr}_{0,85} \mathrm{O}_{1,93}$ atau $92 \mathrm{ZrO}_{2} .8 \mathrm{Y}_{2} \mathrm{O}_{3}$ seperti yang ditunjukkan pada Gambar 6 .

Pada pemanfaatan kernel YSZ untuk riset dan pengembangan pelapisan TRISO, kestabilan fasa zirkonia pada temperaturtemperatur proses pelapisan TRISO merupakan suatu persyaratan yang harus dipenuhi agar tidak terjadi pengerutan dan pemuaian kernel selama proses pelapisan. Larutan padat dengan $8 \% \mathrm{~mol}_{2} \mathrm{O}_{3}$ dan $92 \%$ mol $\mathrm{ZrO}_{2}$ merupakan jumlah minimum mol yttria untuk mendapatkan zirkonia dengan fasa cubic yang stabil dari suhu kamar sampai mendekati suhu lelehnya[28].

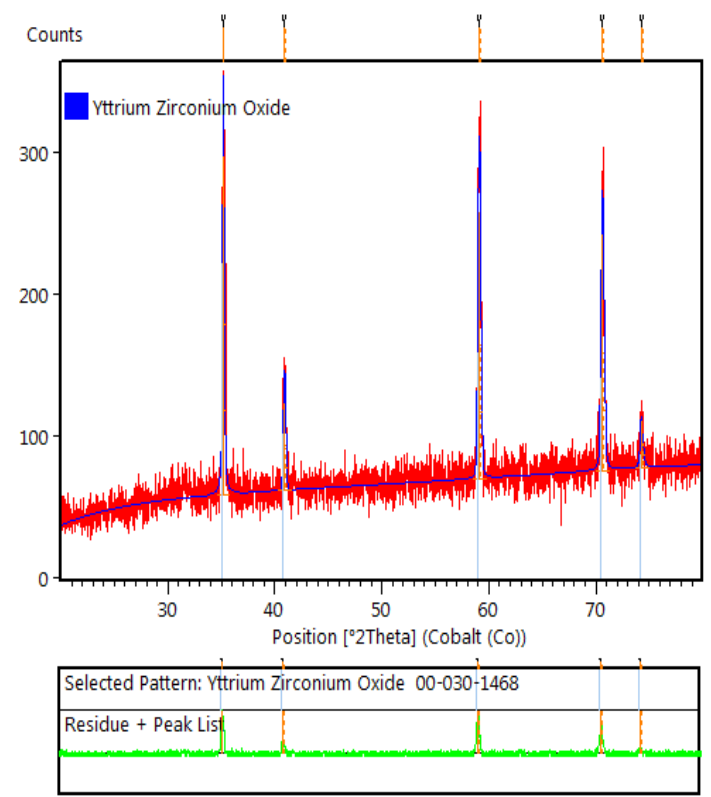

Gambar 6. Identifikasi fasa kernel tersinter menggunakan XRD.

\section{SIMPULAN}

Pada proses fabrikasi kernel YttriaStabilized Zirconia (YSZ) dihasilkan gel hidroksida bersifat amorf dan memiliki porositas yang kurang mencukupi untuk deplesi gas-gas hasil dekomposisi dan dapat mengakibatkan keretakan kernel. Fenomena retak dapat diminimalisir dengan penambahan urea sebagai agen pore promoter. Jumlah urea yang digunakan optimum pada komposisi mol 2,5 kali mol prekursor, dimana sebagian kecil urea terdekomposisi pada preparasi sol umpan. Rute optimum untuk penambahan urea diperoleh pada dekomposisi jumlah urea 1 kali mol prekursor dan penambahan 1,5 kali mol prekursor pada suhu di bawah suhu dekomposisi. Kenaikan konsentrasi prekursor yttrium dan zirkonium menghasilkan diameter kernel YSZ tersinter yang lebih besar, dan untuk mendapatkan kernel dengan diameter tertentu dapat dilakukan penyesuaian konsentrasi prekursor. Penggunaan $0,16 \%$ mol yttrium nitrat dan $84 \%$ mol zirkonium nitrat menghasilkan kernel larutan padat $\mathrm{Y}_{0,15} \mathrm{Zr}_{0,85} \mathrm{O}_{1,93}$ atau $92 \mathrm{ZrO}_{2} .8 \mathrm{Y}_{2} \mathrm{O}_{3}$ dengan fasa cubic dengan densitas 5,5636 $\mathrm{gram} / \mathrm{cc}$ atau 93,34\% densitas teoritis. 


\section{UCAPAN TERIMA KASIH}

Ucapan terima kasih disampaikan kepada rekan-rekan teknisi dan pejabat struktural PTBBN BATAN yang telah membantu melakukan kegiatan eksperimen yang diperlukan untuk penyusunan makalah ini. Kegiatan ini mendapatkan bantuan pendanaan dari Kemenristek Dikti melalui program Flagship Insinas BATAN tahun 2019.

\section{DAFTAR PUSTAKA}

[1] IAEA, "Advances in small modular reactor technology developments," IAEA, Vienna, Austria, 2018.

[2] D. Alberstein, "Weapons grade plutonium destruction in the Gas Turbine Modular Helium Reactor (GT-MHR)," NATO ASI Series: Advanced Nuclear Systems Consuming Excess Plutonium, pp. 135-146, 1997.

[3] IAEA, "High Temperature Gas Cooled Reactor fuels and materials", IAEA TECDOC Series No. 1645, Vienna, 2010.

[4] L. Zhu, et. al., "Uniformity assessment of TRISO fuel particle distribution in spherical HTGR fuel element using Voronoi tessellation and Delaunay triangulation," Science and Technology of Nuclear Installations, vol. 2018, article ID. 7274261, pp. 1-6, 2018.

[5] L. Zhu, X. Xiang, Y. Peng, and X. Wang, "Three-dimensional measurement of TRISO coated particle using micro computed tomography," Science and Technology of Nuclear Installations, vol. 2019, article ID. 2908538, pp.1- 8, 2019.

[6] E. Zimmer, P. Naefe, and H. Ringel, "Aqueous chemical processes for the preparation of high temperature reactor fuel kernels," Radiochimica Acta, vol. 25, no. 3-4, pp. 161-169, 1978.

[7] B. Stringer, P. J. Russell, W. Davies B, and $\mathrm{A}$. Danso K, "Basic aspects of the get-precipitation route to nuclear fuel,"
Radiochimica Acta, vol. 36, pp. 31, 1984

[8] IAEA, "Advances in high temperature gas cooled reactor fuel technology", Vienna, 2013.

[9] Z. Xiangwen, et. al., "Preparation of spherical fuel elements for HTR-PM in INET," Nuclear Engineering and Design, vol. 263, pp. 456-461, 2013.

[10] K. Sawa, S. Ueta, and A. lyoku, "The High Temperature Gas Cooled Reactor Fuel," presented at the GENES4/ANP2003, Sep. 15-19, 2003, Kyoto, Japan.

[11] S. Ueta, J. Aihara, K. Sawa, A. Yasuda, M. Honda, and N. Furihata, "Development of high temperature gascooled reactor (HTGR) fuel in Japan," Progress in Nuclear Energy, vol. 53, no. 7, pp. 788-793, 2011.

[12] K. Sawa, "3.06 - TRISO fuel production," Comprehensive Nuclear Materials, pp. 143-149, 2012.

[13] X. Fu, T. Liang, Y. Tang, Z. Xu, and C. Tang, "Preparation of UO2 kernel for HTR-10 fuel element," Journal of Nuclear Science and Technology, vol. 41, no. 9, pp. 943-948, 2004.

[14] R. Sukarsono, M. Rachmawati, S. Susilowati, D. Husnurrofiq, K. Nurwidyaningrum, and A. Dewi, "Effect of sol concentration, aging and drying process on cerium stabilization zirconium gel produced by external gelation," Journal of Physics: Conference Series, vol. 962, 012056, 2018.

[15] D. A. Petti, J. T. Maki, J. Buongiorno, R. R. Hobbins, and G. K. Miller, "Key differences in the fabrication, irradiation and safety testing of U.S. and German TRISO-coated particle fuel and their implications on fuel performance" Idaho National Engineering and Environmental Laboratory, 2002, Bechtel, Idaho.

[16] J. L. Collins and A. Chi, "Determination of ideal broth formulations needed to 
prepare hydrous cerium oxide microspheres via the internal gelation process," U.S. Department of Energy (DOE) OAK RIDGE NATIONAL LABORATORY, 2008.

[17] P. A. Haas, J. M. Begovich, A. D. Ryon, and J. S. Vavruska, "Chemical flowsheet conditions for preparing urania spheres by internal gelation", OAK RIDGE NATIONAL LABORATORY, 1979.

[18] K. Nagarajan and V. N. Vaidya, "Sol-gel processes for nuclear fuel fabrication," Sol-Gel Processing for Conventional and Alternative Energy, Springer, pp. 341-373, 2012.

[19] R. D. Hunt, F. C. Montgomery, and J. L. Collins, "Treatment techniques to prevent cracking of amorphous microspheres made by the internal gelation process," Journal of Nuclear Materials, vol. 405, no. 2, pp. 160-164, 2010.

[20] G. G. Wang, J. T. Ma, Y. Gao, X. Y. Zhao, S. C. Hao, and C. S. Deng, "Preparation of small size ceria stabilized zirconia microspheres by external gelation: Effect of vibration frequency," Key Engineering Materials, vol. 697, pp. 364-367, 2016.

[21] W. Guogao, M. Jingtao, G. Yong, Z. Xingyu, H. Shaochang, and D. Changsheng, "Precisely controlling preparation of ceria-stabilized zirconia microspheres of $\sim 100 \mu \mathrm{m}$ by external gelation," International Journal of Applied Ceramic Technology, vol. 13, no. 5, pp. 831-837, 2016.

[22] E. Dewita and S. Alimah, "Analisis kinerja bahan bakar reaktor tipe HTGR sebagai penghalang produk fisi," Jurnal
Pengembangan Energi Nuklir, vol. 19, no. 1, pp. 1-9, 2017.

[23] W. F. Skerjanc, J. T. Maki, B. P. Collin, and D. A. Petti, "Evaluation of design parameters for TRISO-coated fuel particles to establish manufacturing critical limits using PARFUME," Journal of Nuclear Materials, vol. 469, pp. 99105, 2016.

[24] K. C. Jeong, S. C. Oh, Y. K. Kim, and Y. W. Lee, "ADU compound particle preparation for HTGR nuclear fuel in Korea," Journal of Industrial and Engineering Chemistry, vol. 13, no. 5, pp. 744-750, 2007.

[25] G. P. Cousland, X. Y. Cui, A. E. Smith, A. P. J. Stampfl, and C. M. Stampfl, "Mechanical properties of zirconia, doped and undoped yttria-stabilized cubic zirconia from first-principles," Journal of Physics and Chemistry of Solids, vol. 122, pp. 51-71, 2018.

[26] K. Vernieuwe, P. Lommens, J. C. Martins, F. Van Den Broeck, I. Van Driessche, and K. De Buysser, "Aqueous $\mathrm{ZrO}(2)$ and $\mathrm{YSZ}$ colloidal systems through microwave assisted hydrothermal synthesis," Materials, vol. 6, no. 9, pp. 4082-4095, 2016.

[27] K. Jyothis and R. Vikas, "Study of conversion of ammonia from urea water solution droplets using CFD," IOP Conference Series: Materials Science and Engineering, vol. 243, 012011, 2017.

[28] A. Raja Annamalai, N. Nagaraju, D. K. Agrawal, and A. Muthuchamy, "Effect of heating mode on sinterability of YSZ+CeO2 ceramics," Metals, vol. 08, no. 03, 2018. 